\title{
Impacts of extratropical storm tracks on Arctic sea ice export through Fram Strait
}

\author{
Jianfen Wei ${ }^{1}\left[\right.$. Xiangdong Zhang ${ }^{2} \cdot$ Zhaomin Wang $^{3}$
}

Received: 22 November 2017 / Accepted: 7 May 2018 / Published online: 16 May 2018

(c) The Author(s) 2019, corrected publication 2019

\begin{abstract}
Studies have indicated regime shifts in atmospheric circulation, and associated changes in extratropical storm tracks and Arctic storm activity, in particular on the North Atlantic side of the Arctic Ocean. To improve understanding of changes in Arctic sea ice mass balance, we examined the impacts of the changed storm tracks and cyclone activity on Arctic sea ice export through Fram Strait by using a high resolution global ocean-sea ice model, MITgcm-ECCO2. The model was forced by the Japanese 25-year Reanalysis (JRA-25) dataset. The results show that storm-induced strong northerly wind stress can cause simultaneous response of daily sea ice export and, in turn, exert cumulative effects on interannual variability and longterm changes of sea ice export. Further analysis indicates that storm impact on sea ice export is spatially dependent. The storms occurring southeast of Fram Strait exhibit the largest impacts. The weakened intensity of winter (in this study winter is defined as October-March and summer as April-September) storms in this region after 1994/95 could be responsible for the decrease of total winter sea ice export during the same time period.
\end{abstract}

Keywords Fram Strait $\cdot$ Sea ice export $\cdot$ Storm track $\cdot$ Cyclones $\cdot$ MITgcm-ECCO2

\section{Introduction}

Fram Strait sea ice export from the central Arctic Ocean into the Greenland-Iceland-Norwegian (GIN) Sea comprises the largest portion of the total Arctic sea ice export (Serreze et al. 2006). On average, about $10-20 \%$ of the Arctic sea ice is transported annually through Fram Strait (e.g., Serreze et al. 2006; Kwok et al. 2009; Spreen et al. 2009). Changes of total Arctic sea ice volume and the mass balance of Arctic multiyear ice are greatly influenced by the changes of Fram Strait sea ice export (e.g., Kwok 2007; Lindsay et al. 2009;

Xiangdong Zhang

xzhang9@alaska.edu

$\triangle$ Zhaomin Wang

zhaomin.wang@hhu.edu.cn

1 Polar Climate System and Global Change Laboratory, Nanjing University of Information Science and Technology, Nanjing 210044, China

2 International Arctic Research Center and Department of Atmospheric Sciences, University of Alaska Fairbanks, Fairbanks, AK 99775, USA

3 College of Oceanography, Hohai University, Nanjing 210098, China
Polyakov et al. 2012). With its high variability, this part of freshwater export is essential for the conditions of North Atlantic deep convection, and thus is extremely important for the entire thermohaline circulation (Hilmer et al. 1998; Koenigk et al. 2006).

Atmospheric forcing processes, especially cyclone activity, could largely determine the variability and changes of Fram Strait sea ice export. In winter, cyclones occur frequently in south of Fram Strait, near the Icelandic low pressure area (Brümmer et al. 2001; Zhang et al. 2004; Rogers et al. 2005; Simmonds et al. 2008; Ulbrich et al. 2009). This region is one of the three pathways for cyclones to propagate northward into the Arctic during winter (Serreze and Barry 1988; Zhang et al. 2004). Those cyclones play an important role with both thermodynamic and dynamic impacts in the sea ice motion through Fram Strait, especially with the drastic retreat and thinning of Arctic sea ice cover in recent years. The intensified surface wind stress during a cyclone process, which is the most significant external force to sea ice motion, could dramatically shift the local ice drift motion and consequently affect the sea ice distribution and the southward Arctic sea ice outflow through Fram Strait into the GIN Sea (Rogers et al. 2005; Spall 2007; Brümmer et al. 2008). Intensive cyclones can also induce drastic ice 
decline due to the increased bottom melting by the windinduced enhanced oceanic mixing (Murray and Simmonds 1995; Inoue and Hori 2011; Zhang et al. 2013), or by transporting warm air over the sea ice areas (Boisvert et al. 2016).

Brümmer et al. (2001) have studied the properties and variabilities of cyclones near Fram Strait by both in situ observations and long-term time series from reanalysis data. The impact of cyclone activity within this area on sea ice have also been investigated previously by observations (Brümmer et al. 2001, 2003, 2008), atmospheric reanalysis (e.g., Rogers et al. 2005) or model simulations (e.g., Dierer et al. 2005; Zhang et al. 2013). The impacts of cyclones on sea ice depend on the location of cyclone tracks, which mainly determines the direction of ice drift and the amount of ice convergence (Brümmer et al. 2001; Dierer et al. 2005; Tsukernik 2007; Liptak and Strong 2013). In addition, different counts, sizes, intensities and developmental stages of cyclones also have different effects on the sea ice motion (Brümmer et al. 2001; Rogers et al. 2005; Lammert et al. 2009).

Interannual variations in cyclone intensity and count are closely related to the large-scale atmospheric circulations such as the Arctic Oscillation (AO) or the North Atlantic Oscillation (NAO), which is associated with changes of mean SLP over the Arctic (Serreze et al. 1997; Simmonds et al. 2008). Since late 1990s, the Arctic has been warming more than twice as rapidly as the global average (Screen and Simmonds 2010; Cohen et al. 2014), and the downward trends have continued in Arctic sea ice thickness and extent (e.g., Cavalieri and Parkinson 2012; Laxon et al. 2013; Lindsay and Schweiger 2015). With these unprecedented changes, the Arctic climate is being replaced by a new climate state, which is warmer, wetter and more variable than before. The large-scale atmospheric circulation patterns in the northern hemisphere have also experienced great modifications.

A poleward shift of North Atlantic storm track in the second half of the twentieth century has been diagnosed in climate model simulations (Yin 2005; Ulbrich et al. 2009), and has been linked to the changes of storm activity over the northern part of the North Atlantic Ocean (McCabe et al. 2001; Lambert and Fyfe 2006). In addition, since the mid-1990s, a radical shift of Northern Hemisphere leading atmospheric circulation from conventional tri-polar $\mathrm{AO}$ to a more meridional dipole-structure pattern has been reported (Zhang et al. 2008; Overland and Wang 2010). This shift could be an integrative manifestation of poleward shift of storm tracks and intensification of Arctic storm activity (Zhang et al. 2008). Atmospheric reanalysis datasets are commonly adopted to investigate the synoptic cyclone activity on the hemispheric scale. Hodges et al. (2011) analyzed the statistics of extratropical cyclones in the Northern and Southern Hemisphere tracked in four modern reanalyzes.
They found that these reanalyzes show a very similar spatial distribution of North Atlantic cyclones and a good one-toone cyclone correspondence over the Northern Hemisphere, which gives us confidence to study the cyclones using reanalysis data. It is expected that variability and changes of local cyclone activity may show great differences from those in the whole hemisphere, thus needs further research on it.

In this paper, we use a global high-resolution coupled ocean-sea ice model, a high-resolution atmospheric reanalysis dataset and a reliable cyclone algorithm to synthetically investigate the characteristics of cyclones near Fram Strait and their relationship with Arctic sea ice export through the strait in the context of shifting atmospheric circulation. The reanalysis data used in this study is the Japan Meteorological Agency and Central Research Institute of Electric Power Industry 25-year reanalysis (JRA-25; Onogi et al. 2007). The data is also the atmospheric forcing of our coupled model. It extends from 1979 to 2012, which is long enough for us to analyze the statistical features of the cyclones, and has been proved having good performance in identifying cyclones in the North Atlantic (Hodges et al. 2011). The paper is organized as follows: Sect. 2 briefly introduces the coupled ocean-sea ice model and the forcing data, as well as the identification and tracking algorithm of cyclones. Section 3 presents the variability and changes of cyclones near Fram Strait based on both case study and statistical analysis. Section 4 explores the cyclone impacts on sea ice motion and the resultant sea ice export through Fram Strait. The summarized conclusions and the discussion are given in Sect. 5 .

\section{Materials and methods}

\subsection{Model description and atmospheric forcing data}

The Arctic sea ice data (including sea ice concentration, ice thickness and ice velocity) used in this study was obtained from the Massachusetts Institute of Technology general circulation model (MITgcm; Marshall et al. 1997a, b) in the state estimate configuration Estimating the Circulation and Climate of the Ocean, phase 2 (ECCO2), high-resolution global ocean and sea ice data synthesis. The ocean model is coupled with a sea ice model that simulates a viscousplastic rheology (Losch et al. 2010). The coupled ocean-sea ice model is run forward using optimized control parameters obtained through reducing model-data misfit by using the Green Function approach (Menemenlis et al. 2005a, b, 2008). The modes ability to reproduce important Arctic Ocean water masses (such as the warm Atlantic water and cold halocline) and to describe a real distribution of Arctic sea ice cover has been demonstrated better than the other models that participated in Arctic Ocean Model 
Intercomparison Project (AOMIP) (Menemenlis et al. 2008a, b; Nguyen et al. 2009, 2011). Detailed description (including the initialization) of this model and its application can be found in Menemenlis et al. (2008a, b).

The atmospheric forcing was provided by the JRA-25, with a spatial resolution of $1.125^{\circ} \times 1.125^{\circ}$. The model was forced by the JRA- 25 atmospheric data every $6 \mathrm{~h}$ and was integrated for 34 years from 1979 to 2012 . The long-term, high temporal resolution (6-hourly) model simulation results are particularly useful for this study, as available satellite and in-situ sea ice observations are sparse and incomplete.

\subsection{Identification and tracking of cyclones}

To investigate cyclone activity near Fram Strait, we applied a reliable cyclone identifying and tracking algorithm (Serreze 1995; Serreze et al. 1997) to the 6-hourly Sea Level Pressure (SLP) in the JRA-25 reanalysis dataset. This algorithm identifies a cyclone center by looking for points with a minimum SLP gradient greater than a given threshold with surrounding grid points. The cyclone track is defined as the trajectory of a cyclone center. The cyclone intensity is defined as the mean absolute values of the difference between the central SLP of cyclones and the climatological monthly mean SLP at corresponding grid points throughout each cyclone process. Then cyclone count and cyclone duration are used to describe different aspects of cyclone activities. This algorithm has been extensively tested and used to explore extratropical cyclones and their impacts on weather and climate (Zhang et al. 2004, 2012; Rogers et al. 2005; Wang et al. 2006; Finnis et al. 2007; Stroeve et al. 2011). Zhang et al. (2004) improved this method to remove troughs extended from cyclones and minimize the effects of irregular troughs or departures. More details of this algorithm and its application to investigate the variability and changes of Northern Hemisphere storm activity can be found in Zhang et al. (2004). Using this algorithm, we archive a comprehensive description of cyclone activity, including cyclone count, intensity, duration and the location of the cyclone centers at every 6-h time step along each cyclone trajectory. In this study, we only consider the trajectory of the cyclone that lasts for a minimum duration of $12 \mathrm{~h}$.

\section{Cyclone activity near Fram Strait}

\subsection{A case study}

In our study region $\left(60^{\circ} \mathrm{N}-87^{\circ} \mathrm{N}, 40^{\circ} \mathrm{W}-60^{\circ} \mathrm{E}\right.$, shown in Fig. 1), climatological low pressure occupies the area from southwest of the Iceland extending to the Barents Sea and Kara Sea. The extent of this region is exactly consistent with the common track of most cyclone activity, i.e., from

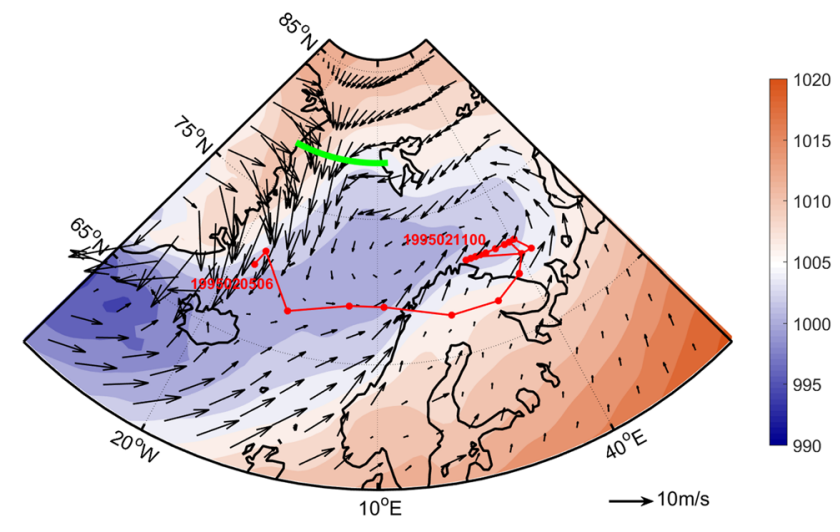

Fig. 1 The trajectory of a cyclone (red line) occurred in February 1995 and the location of the vertical cross-section (green curve, $78.875^{\circ} \mathrm{N}, 20.125^{\circ} \mathrm{W}-13.625^{\circ} \mathrm{E}$ ) for calculating Fram Strait sea ice export. The red dots denote the positions of cyclone center in each 6-hourly snapshot. Color and vectors are the climatology of winter (December-February) SLP (hPa) and $10 \mathrm{~m}$ wind (m/s) during 19792012

southwest to northeast. Here we focus on a typical cyclone process that occurred in February 1995. The trajectory of this cyclone is shown in Fig. 1. The cyclone generated near the southeast of Greenland, and moved eastward into the Southern Barents Sea where it dissipated. The cyclone duration was $144 \mathrm{~h}$ from 0600 UTC 05 February to 0000 UTC 11 February 1995 . The intensity of this cyclone, which is defined as the mean absolute value of the difference between the central SLP of the cyclone and the climatological monthly mean SLP at corresponding grid points over the cyclone duration, reached a maximum of about $47 \mathrm{hPa}$.

During the passage of this cyclone, the intensive anomalous northerly wind persisted due to the large cross-strait east-west difference of sea level pressure (SLP) (Fig. 2). Here the anomalies of SLP/wind are the differences between 6-hourly SLP/wind and climatological mean SLP/wind in February during 1979-2012. Same as the anomalies of 6-hourly sea ice thickness/velocity in Fig. 3. It is noteworthy that the center of this cyclone stayed for a much long time in the southeastern side of Fram Strait during this cyclone process. Consequently, sea ice drift was strikingly driven from Arctic Ocean through Fram Strait into the GIN Sea (Fig. 3). The anomalous thicker ice within the strait, which was probably due to the convergence driven by the abnormal surface wind field, also contributed to the significant increase of sea ice export during this cyclone process.

We derived the daily Fram Strait sea ice volume export based on MITgcm-ECCO2 simulation during this cyclone track. As shown in Fig. 4a, sea ice export responses instantaneously to the cyclone-induced strong wind on synoptic time scale. Clearly the meridional ice velocity across the vertical section within the strait is highly correlated with the total sea ice export (the correlation coefficient is +0.94 , passing $99 \%$ 


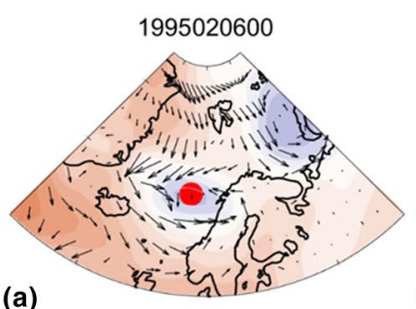

(a)

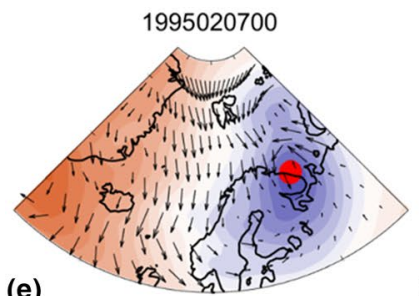

(e)

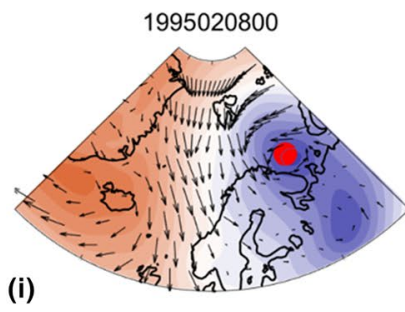

(b)

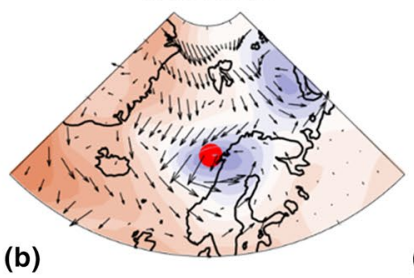

1995020706

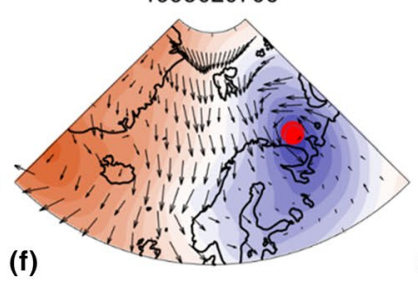

(c)

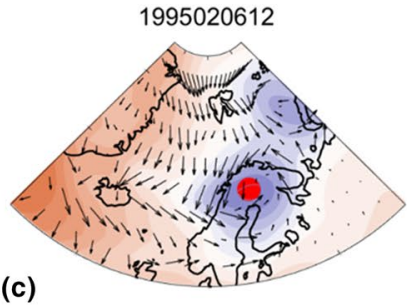

1995020712

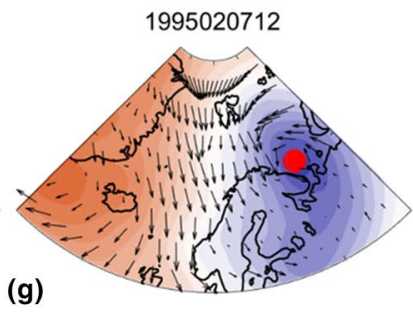

(g)

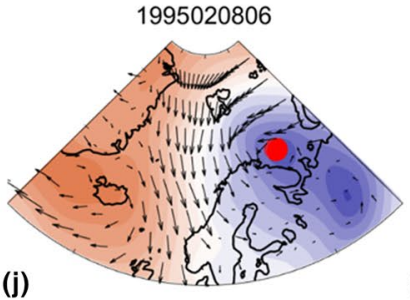

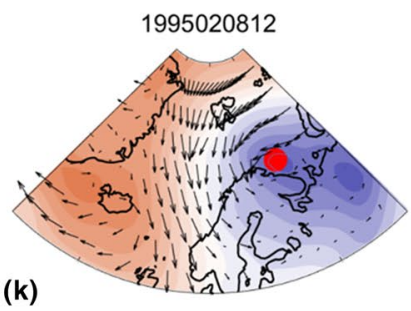

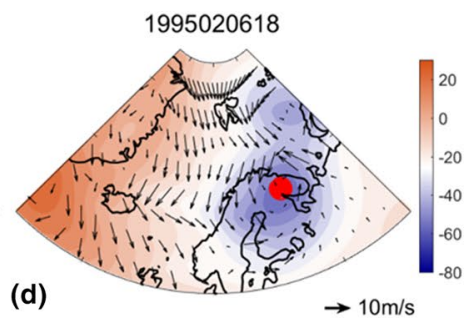

(d)

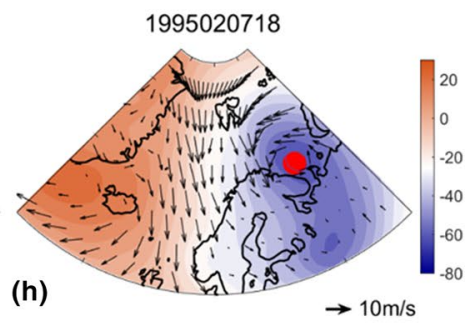

Fig. 2 The anomalies of SLP (color) and $10 \mathrm{~m}$ wind (vectors) during the cyclone track in February 1995. The red dots denote the positions of cyclone center in each 6-hourly snapshot. The unit of the color bar is (hPa)
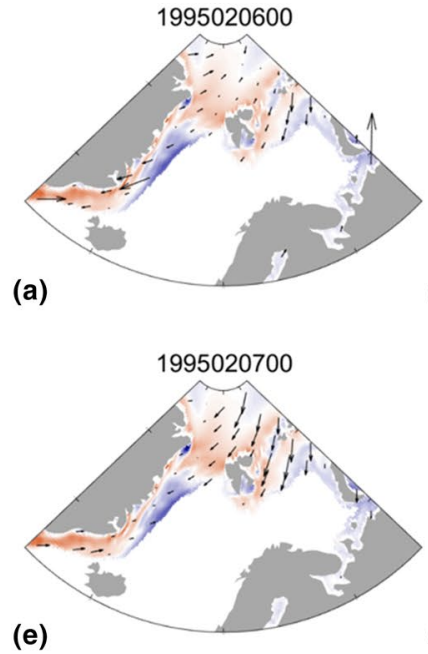

(e)

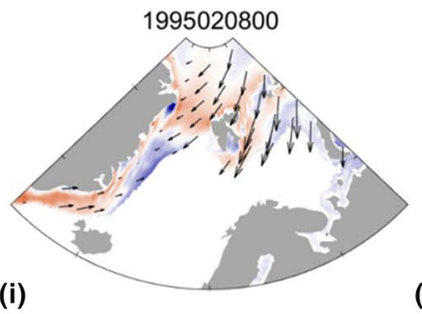

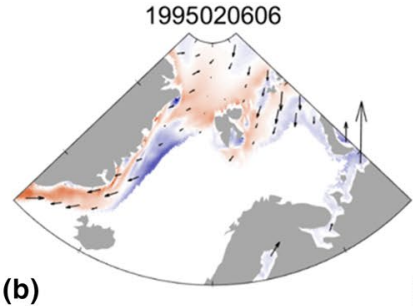

(c)
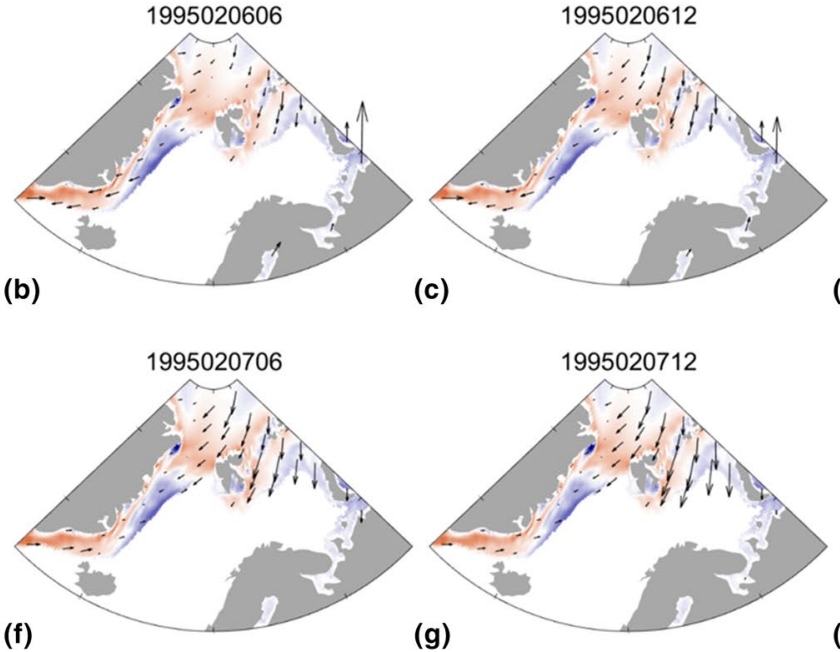

(g)
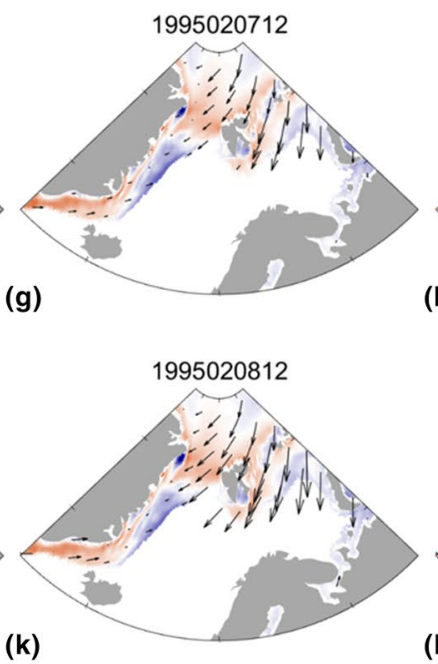

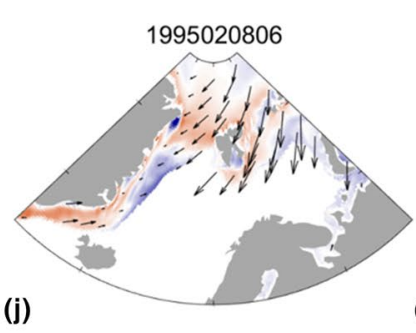

(d)

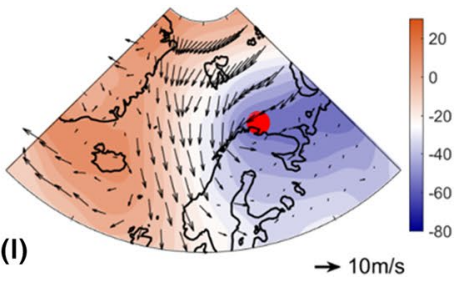

(h)
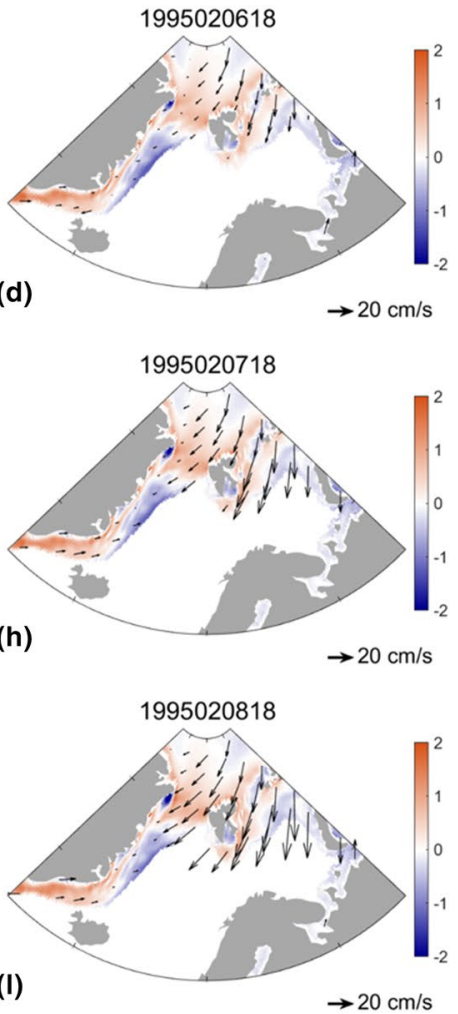

Fig. 3 The anomalies of sea ice thickness (color) and sea ice velocity (vectors) during the cyclone track in February 1995. The unit of the color bar is (m) 
Fig. 4 Time series of daily a meridional wind stress, $\mathbf{b}$ meridional ice velocity, $\mathbf{c}$ ice thickness, and $\mathbf{d}$ ice concentration across the vertical section within Fram Strait during the cyclone track in February 1995. The dashed line in $\mathbf{a}$ is the sea ice volume export through Fram Strait. Note that the signs of the wind stress and ice velocity are reversed
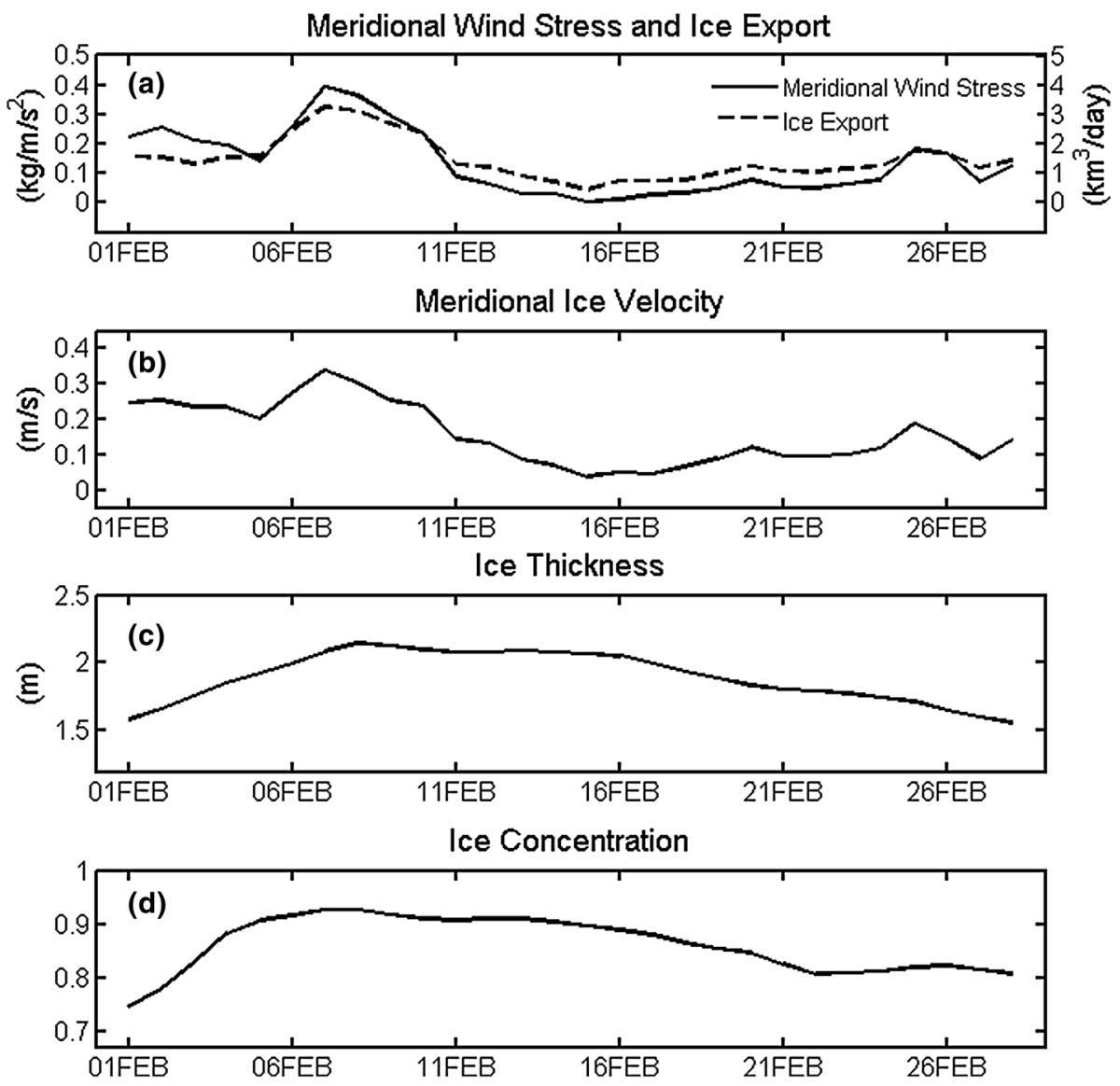

confidence level), while the sea ice thickness and concentration along the cross-section show relatively weak correlations (Fig. 4b-d). The result may suggest that the variability of sea ice volume export is largely contributed by the variability of meridional ice velocity, which is consistent with the conclusion of Lindsay and Zhang (2005). According to the scale analysis of momentum equation of sea ice motion, surface wind stress is one of the dominant driving forces on the sea ice drift (Thorndike and Colony 1982; Leppäranta 2005). Thus, sea ice export through Fram Strait is closely dependent on the changes of cyclone-induced strong wind near the strait.

\subsection{Statistical analysis}

Based on the cyclone identifying and tracking algorithm of Zhang et al. (2004), all of the cyclones occurred during 1979-2012 in the entire study region (shown in Fig. 1) were counted and analyzed. As shown in Fig. 5, mean intensity of cyclones near Fram Strait is greater in winter (October-March) than in summer (April-September). In contrast, both cyclone count and cyclone duration show weak seasonal variations. There are more cyclone trajectories in May-July than in other months, while cyclones occurred in August-November show longer durations among

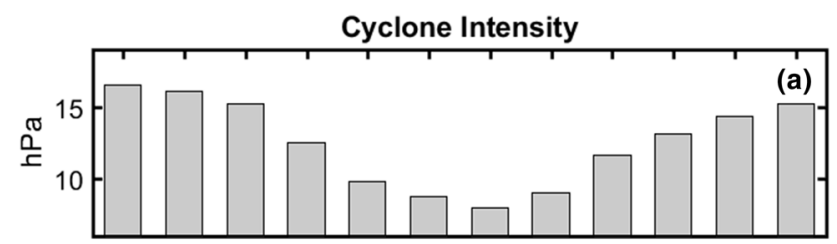

Jan Feb Mar Apr May Jun Jul Aug Sep Oct Nov Dec Cyclone Trajectory Count

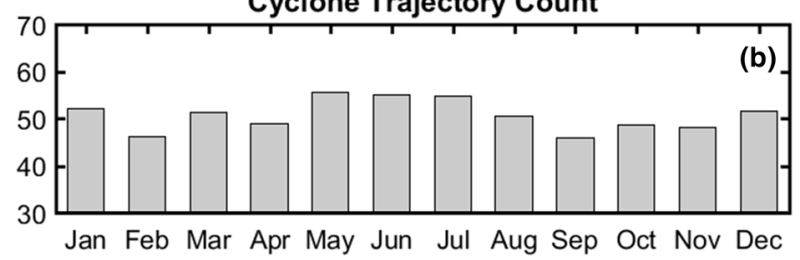

Cyclone Duration

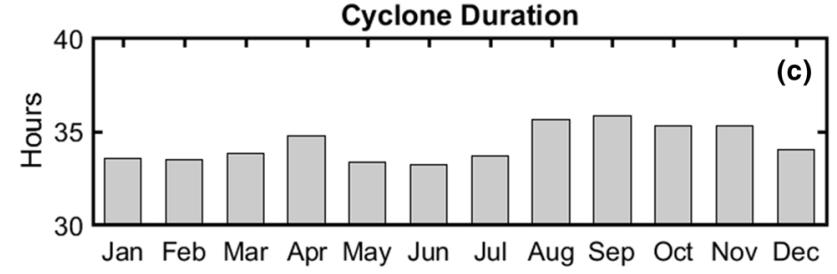

Fig. 5 Climatological seasonal cycle of cyclone trajectory a intensity, b count and c duration over the period 1979-2012 
the whole year. The seasonal cycle of cyclone intensity and cyclone trajectory count in Fig. 5 a, b is highly consistent with the results from Zhang et al. (2004) (see their Fig. 3a, b), although they focused on a different region (from $60^{\circ}$ to $90^{\circ} \mathrm{N}$ ). Wei et al. (2017) also investigated the seasonal and inter-annual variations of cyclone activity in the Arctic region (from $70^{\circ}$ to $85^{\circ} \mathrm{N}$ ) using an automatic cyclone tracking algorithm developed by University of Reading. This scheme identifies the low-pressure system based on the minimum pressure or maximum relative vorticity derived from ERA-Interim mean SLP data. The minimum cyclone track duration $(12 \mathrm{~h})$ in their study is the same as ours. The maximum center pressure is limited to less than $1000 \mathrm{hPa}$, while it is not specified in our study. The seasonal variation of cyclone intensity in Wei et al. (2017) is also in consistency with Fig. 5a, with much weaker cyclones occurring in summer. However, the maximum number of Arctic cyclones counted in winter (December-February) and the minimum in spring (March-May) from Wei et al. (2017) are different from our results in Fig. 5b, which may be attributed to the difference in study regions.

The climatology of spatial distribution ofcyclone activity nearFram Strait is shown in Fig. 6. We composited the cyclone center count and cyclone center SLP into $5.0^{\circ} \times 5.0^{\circ}$ grid cells. In both winter and summer, cyclones occur more frequently in southeast of Fram Strait and the southern
Barents Sea (Fig. 6a, b), while the cyclone count is slightly less in summer than in winter. The locations of maximum cyclone frequency between Norway and Svalbard are highly consistent with those in Wei et al. (2017) (see their Fig. 3b, d). Although based on quite different cyclone track schemes and reanalysis datasets, as well as different definitions of seasons, the two fields show broadly similar spatial patterns for both winter and summer cyclone frequency. The large local maximum in cyclone frequencies over Greenland (with high topography) is probably caused by the negative biases induced by the extrapolation of pressure to sea level, as pointed out by Zhang et al. (2004). The distribution of cyclone center SLP is consistent with the climatological SLP distribution, with greater low pressure extending from Iceland into Arctic Ocean. As an indicator of cyclone intensity, the significant seasonal variation of cyclone center SLP implies much stronger cyclones occurring in winter than in summer within our study region.

The characteristic quantities of cyclones nearFram Strait show great interannual variations during 1979-2012, with larger variations occurring in winter, especially for the cyclone intensity. In addition, variability of total annual Arctic sea ice export through Fram Strait is dominated by the high variability of ice export in winter (figure omitted). Thus the connection betweencyclone activity and sea ice export during the winter season isthe main concern in this study.
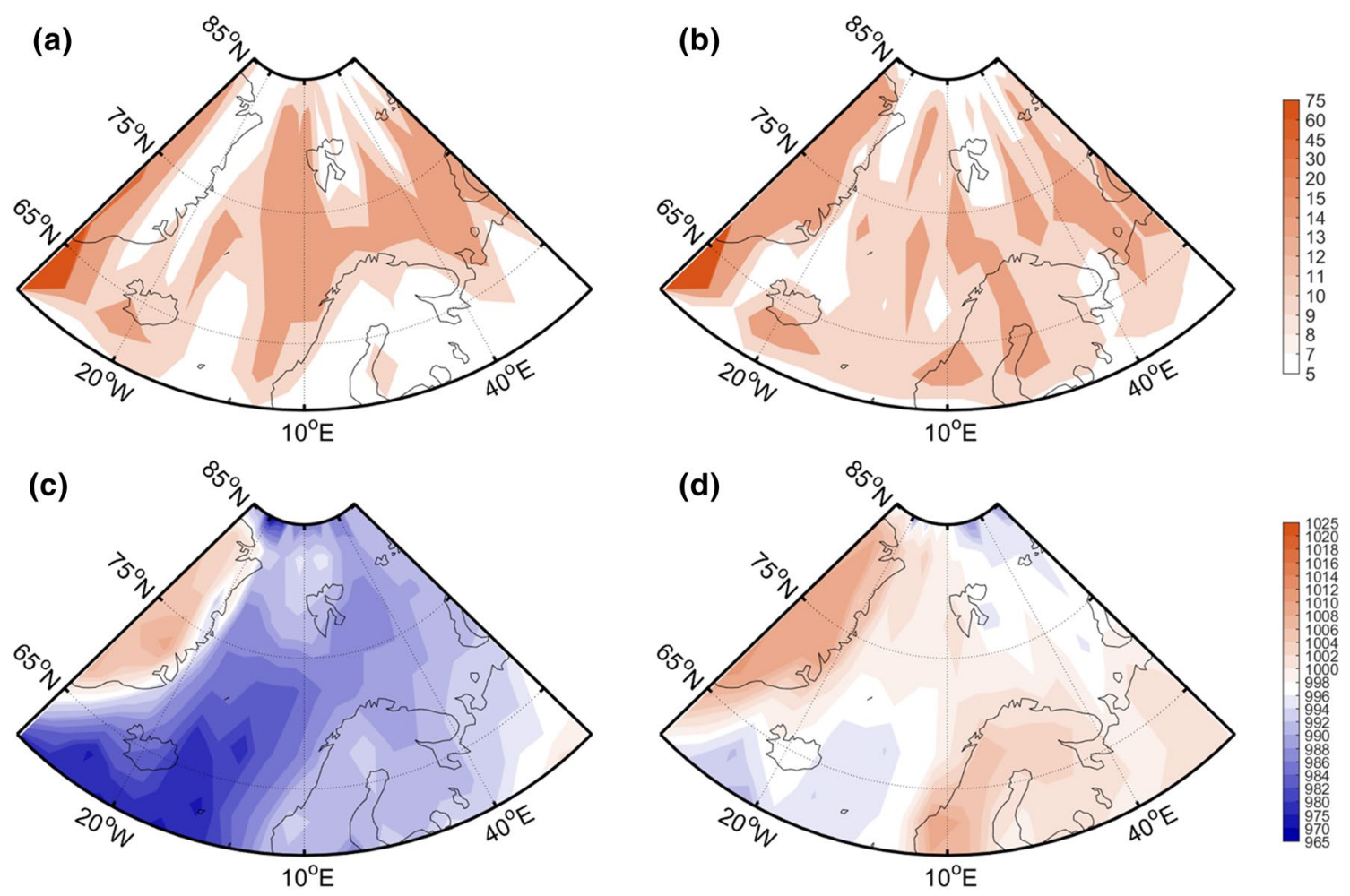

Fig. 6 The climatology of cyclone center count in $\mathbf{a}$ winter and $\mathbf{b}$ summer; and the climatology of mean SLP of cyclone centers in $\mathbf{c}$ winter and $\mathbf{d}$ summer. The unit of the color bar for $\mathbf{a}, \mathbf{b}$ is (counts per $10^{5} \mathrm{~km}^{2}$ ), and for $\mathbf{c}, \mathbf{d}$ is (hPa) 
As shown in Fig. 7, there is no obvious long-term trend in the count and intensity of cyclonesin the entire study region (shown in Fig. 1) during 1979-2012. The insignificant trend of cyclone count was also found by Wei et al. (2017). However, if separated into two time periods before and after the mid-1990s, winter cyclone intensity shows a great decrease in the latter period (with the difference between the two periods passing $95 \%$ confidence level based on the twosample $t$ test), indicating a decadal time scale variability of cyclones near the strait. Meanwhile, there is no significant difference in winter cyclone count and duration between the two periods.

Previous studies have linked the variability of cyclone activity to AO/NAO. In our research area, winter cyclone intensity is highly correlated with winter (October-March)
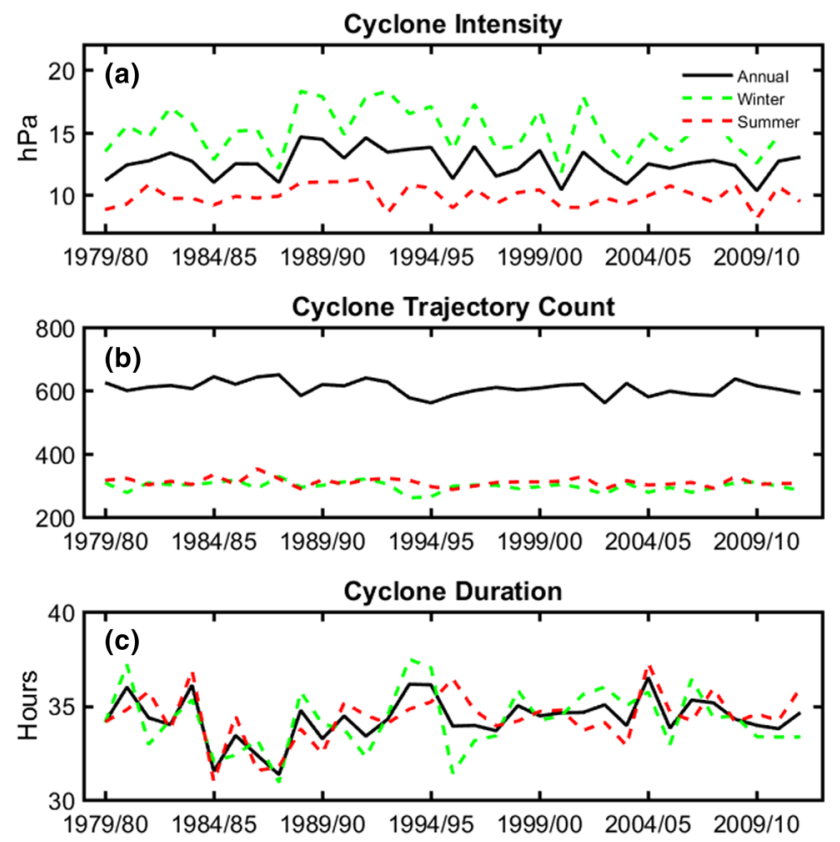

Fig. 7 a Time series of annual (black solid lines), winter (green dashed lines) and summer (red dashed lines) mean cyclone intensity in the entire study region during 1979-2012. b, c are the same as a, but for cyclone count and cyclone duration, respectively
AO index during 1979-2012 (figure omitted). The significant positive correlation coefficient between them $(+0.85$, passing the $99 \%$ confidence level) indicates that the intensity of winter cyclones near Fram Strait is largely controlled by the adjustment of atmospheric circulation patterns associated with AO.

Based on the research of Zhang et al. (2008), the atmospheric circulation pattern in the Northern Hemisphere has experienced a systematic spatial shift since the mid-1990s, transforming from the conventional tri-polar $\mathrm{AO} / \mathrm{NAO}$ to an unprecedented dipolar (between the Eurasian Arctic coast and North Pacific) leading pattern, named "Arctic Rapid change Pattern" (ARP). During positive ARP years, the northerly wind over the strait is strengthened, while in negative ARP years, the reverse is the case. The recently negative-dominant phase of the new circulation leading pattern (figure omitted) seems not to favor the development of cyclone activity near Fram Strait due to changes of the associated hemispheric-scale, meridionally-transformed wind flow.

\section{Relationship between cyclones and sea ice export through Fram Strait}

In our study, the mean winter cyclone intensity in the entire study region shows a high correlation (+ 0.66 , passing $99 \%$ confidence level) with winter sea ice export through the strait during 1979-2012 (Fig. 8). The obvious reduction of the sea ice export is well coincided with the decrease of mean cyclone intensity after the mid-1990s. The spatial distribution of winter cyclone center count and cyclone center SLP were composited during high (1980/81, 1988/89, 1991/92, 1992/93, 1994/95) and low (1979/80, 1984/85, 1998/99, 2002/03) ice export winters (Fig. 9). In south of Fram Strait, cyclone count was lower, and the SLP of cyclone centers was much higher in low ice export years than in high ice export years.

Figure 9 shows that the interannual impact of cyclone activity on Fram Strait sea ice export is spatially dependent.
Fig. 8 Winter (October-March) cyclone intensity averaged over the entire study region and sea ice export through Fram Strait during 1979-2012

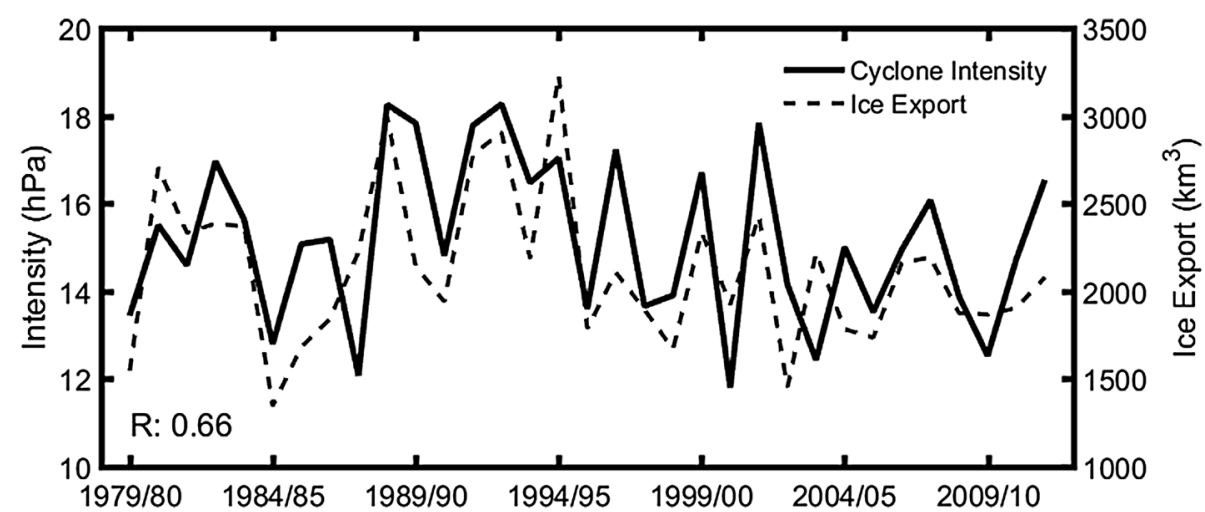



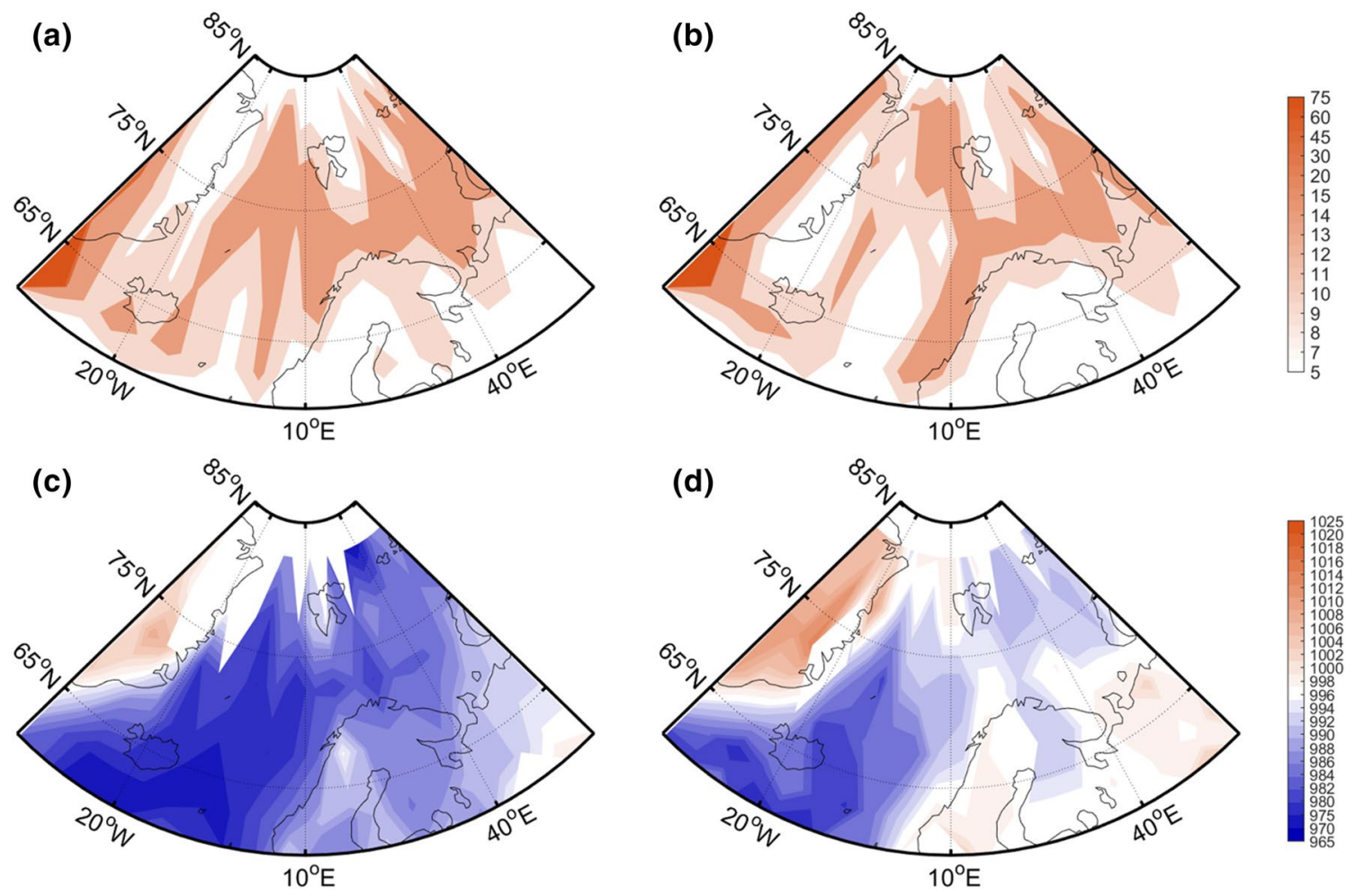

Fig. 9 Composite maps of winter cyclone center count during a high ice export years and $\mathbf{b}$ low ice export years, and the composite maps of winter mean SLP of cyclone centers during $\mathbf{c}$ high ice export years

and $\mathbf{d}$ low ice export years. See the text for details of the composition process. The unit of color bars in $\mathbf{a}, \mathbf{b}$ is (counts per $10^{5} \mathrm{~km}^{2}$ ), and in $\mathbf{c}, \mathbf{d}$ is $(\mathrm{hPa})$

To explore the relationship between changes of cyclone activity in different regions and changes of ice export through Fram Strait, normalized winter cyclone center count and the spatially averaged cyclone center SLP in each $5.0^{\circ} \times 5.0^{\circ}$ grid cell were regressed upon the winter sea ice export anomaly. Here the cyclone center SLP anomaly is defined as the absolute value of the difference between the central SLP of each cyclone center and the climatological

monthly mean SLP at corresponding grid points. Cyclone center SLP anomaly could well represent the intensity of each cyclone center, and was used to analyze the spatiallydependent cyclone impact on sea ice export. As shown in the regression maps in Fig. 10, the key region for cyclones to influence the interannual variability of sea ice export is located in the southeast of Fram Strait (dashed box), with more frequent cyclone centers and greater cyclone center
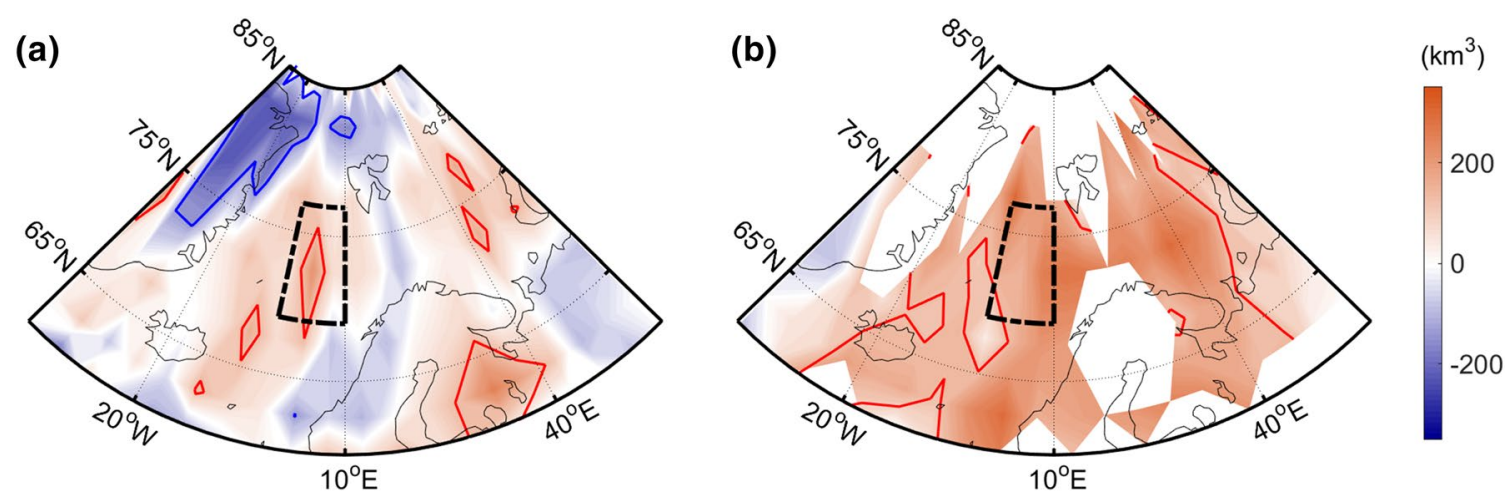

Fig. 10 Regression maps of normalized winter a cyclone center count and b cyclone center SLP onto the winter sea ice export anomaly through Fram Strait. Note that the sign in b is reversed. Enclosed areas by solid (red and blue) lines denote significant regression coef-

ficients at $90 \%$ confidence level based on the Student's $t$ test. The key region for cyclones to impact ice export variability is marked by the black dashed line 
SLP anomalies occurring during higher ice export winters. Note that the negative significant regression coefficients over eastern Greenland in Fig. 10a is not physically meaningful. The cyclone count in this region is very low in winter and the pressure tends to be high (Fig. 6a, c). Figure 11 shows a very weak increasing trend of winter cyclone center count in this key region, while the mean SLP anomalies (with the

\section{Cyclone Center Count}
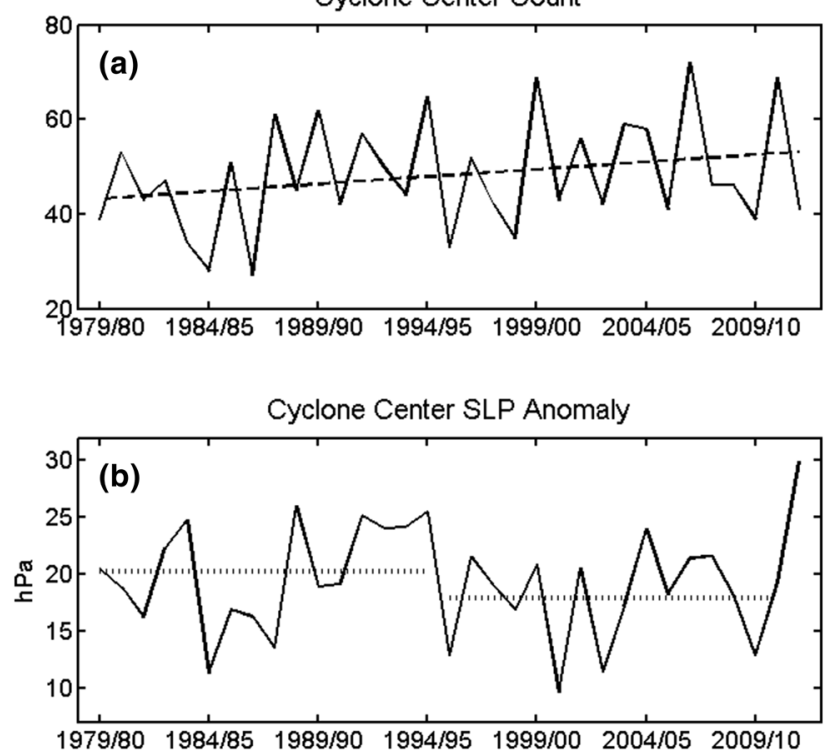

Fig. 11 Time series of winter a cyclone center count and $\mathbf{b}$ cyclone center SLP anomaly within the key region during 1979-2012. The key region is shown in Fig. 10. The dashed line in a denotes the linear trend of the cyclone center count. The dotted lines in $\mathbf{b}$ denote the average values of cyclone center SLP anomaly during 1979/801994/95 and 1995/96-2010/11, respectively. Note that the sign of SLP anomaly in $\mathbf{b}$ has been reversed

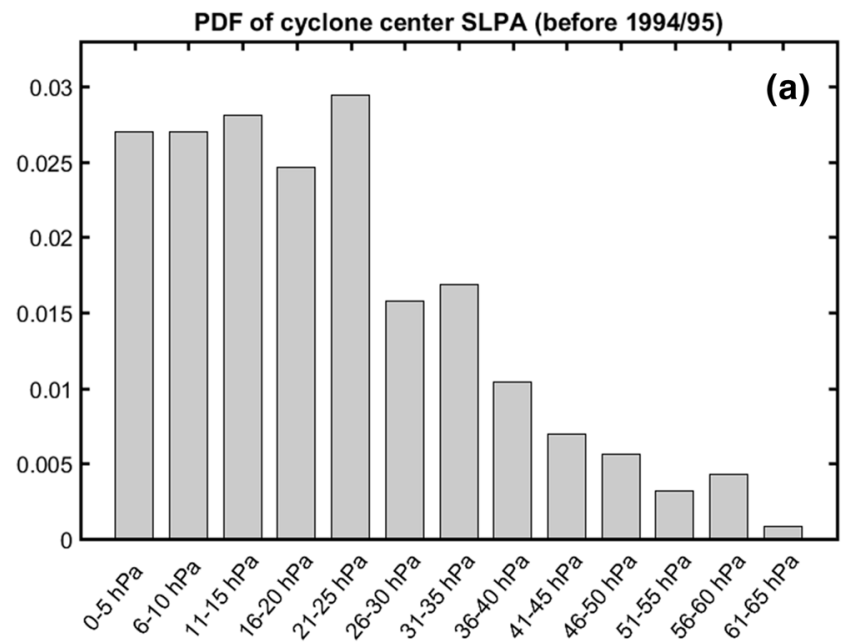

sign reversed), which could well represent the intensity of cyclone centers, have decreased strikingly after 1994/95, except for the dramatic maximum occurring in winter of 2011/12. More research work is needed to explain this maximum of cyclone center SLP anomaly, which is beyond the scope of this study. Based on the two-sample t-test, the decrease of the mean cyclone center SLP anomaly during 1995/96-2010/11 is significant at $90 \%$ confidence level (Fig. 11b). These results indicate that although no significant trend of cyclone intensity or count is found either locally or in the whole study region (figures omitted), the cyclone intensity characterized by the cyclone center SLP anomaly does exhibit a significant decadal scale variability during 1979-2012. This decrease occurring in the mid-1990s is consistent with the results about cyclone intensity shown in Fig. 7a.

The probability density function (PDF) of winter cyclone center SLP anomalies within the key region provides another evidence of the weakening of cyclones in the key region. The PDF (Fig. 12) shows a much higher percentage of weak cyclones (with intensity lower than $20 \mathrm{hPa}$ ) after the mid-1990s, indicating a weakening tendency of cyclones near Fram Strait in recent years. Combined with the regression maps mentioned above, this study indicates that storm impact on sea ice export is spatially dependent, with the largest impacts occurring southeast of Fram Strait. The weakened intensity of winter storms in this region after 1994/95 could be responsible for the decrease of total winter sea ice export during the same time period.

Some studies have indicated a poleward shift of extratropical storm tracks (Zhang et al. 2004; Bengtsson et al. 2006). Along with the changes of storm track in the Northern Hemisphere, Zhang et al. (2004) found an intensification of Arctic storm activity, particularly on the North Atlantic

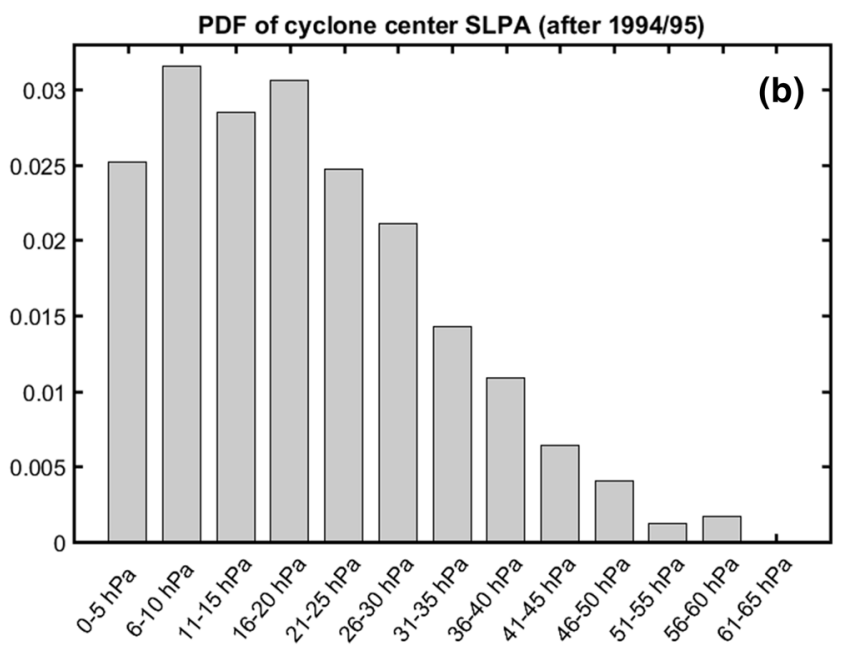

Fig. 12 Probability density function (PDF) of winter cyclone center SLP anomaly in the key region a before 1994/95 and b after 1994/95. The key region is shown in Fig. 10. Note that the sign of SLP anomaly has been reversed 
side of the Arctic Ocean. This research shows that changes of the characteristics of local cyclones nearFram Strait are different from changes of cyclones in the whole Arctic region. The recently weakened cyclones southeast of Fram Strait have induced the decrease of total Arctic sea ice export through the strait.

\section{Conclusions}

A high-resolution global ocean and sea-ice model MIT$\mathrm{gcm}-\mathrm{ECCO} 2$ has been used to explore the impacts of local cyclone activity on Fram Strait sea ice export by both case study and statistical analyses. During 1979-2012, mean intensity of cyclones near Fram Strait is much greater in winter (October-March) than in summer (April-September), while both cyclone count and cyclone duration show weak seasonal variations. Cyclone centers are mainly located to the southeast of Greenland in both seasons, with the greatest low SLP of cyclone centers located near the Iceland. The cyclone intensity in winter shows larger interannual variation than in summer during 1979-2012. In this study, no obvious long-term (1979-2012) trend of cyclone count or cyclone intensity is found near Fram Strait. However, if we separate the whole study period into two parts of 1979/80-1994/95 and 1995/96-2011/12, the winter cyclone intensity shows a great decrease in the latter period, indicating a decadal time scale variability of the cyclone activity near the strait. Meanwhile, there is no significant difference in winter cyclone count and duration between the two periods.

Daily sea ice export simultaneously responds to the cyclone-induced strong surface wind mainly through the significantly strengthened cross-strait sea ice meridional motion during each cyclone passage. This study shows that the cumulative effects of cyclone-induced strong surface wind (on synoptic time scale) could greatly influence the interannual variability and long-term changes of total sea ice export through Fram Strait.

The impact of cyclone activity on sea ice motion and the associated sea ice export through Fram Strait is spatially dependent. Regression maps of winter cyclone count and intensity on Fram Strait sea ice export indicate that cyclones occurring southeast of Fram Strait exhibits the largest impacts on the variability of sea ice export. According to the PDF results of the averaged cyclone center SLP anomaly over the key region before and after the mid-1990s, the weakened intensity of winter cyclones in this region after 1994/95 could be responsible for the decrease of total winter sea ice export during the same period.

The great interannual and decadal variability of cyclones nearFram Strait may have close relationship with changes of Arctic climate system in recent years. Many studies have demonstrated the responses of large-scale atmospheric circulation and the associated cyclone track to the accelerated decline of Arctic sea ice cover (e.g., Inoue et al. 2012). With the continuously changing of Arctic climate state, the atmospheric circulation pattern may be completely modified. The high correlation existing previously between cyclone behavior near Fram Strait and AO/NAO may probably not continue to hold in the future. More studies are need to investigate the possible factors responsible for the changes of cyclone track and the associated changes of Arctic sea ice motion in different regions.

Acknowledgements This study was supported by the National Key R\&D Program of China (2016YFA0601804), the Ministry of Science and Technology of China (Grant 2015CB953900), and the Research Innovation Program for College Graduates of Jiangsu Province (KYLX15_0857). ZW is supported by "the Fundamental Research Funds for the Central Universities" (2017B20714; 2017B04814). JRA25 reanalysis data were obtained freely from the NCAR's research data archive (https://rda.ucar.edu/datasets/ds625.0/).

Open Access This article is distributed under the terms of the Creative Commons Attribution 4.0 International License (http://creativecommons.org/licenses/by/4.0/), which permits unrestricted use, distribution, and reproduction in any medium, provided you give appropriate credit to the original author(s) and the source, provide a link to the Creative Commons license, and indicate if changes were made.

\section{References}

Bengtsson L, Hodges KI, Roeckner E (2006) Storm tracks and climate change. J Clim 19:3518-3543. https://doi.org/10.1175/JCLI3815.1

Boisvert L, Petty A, Stroeve J (2016) The impact of the extreme winter 2015/16 Arctic cyclone on the Barents-Kara Seas. Mon Weather Rev 144:4279-4287. https://doi.org/10.1175/mwr-d-16-0234.1

Brümmer B, Müller G, Affeld B, Gerdes R, Karcher M, Kauker F (2001) Cyclones over Fram Strait: impact on sea ice and variability. Polar Res 20(2):147-152. https://doi.org/10.3402/polar.v20i2.6511

Brümmer B, Müller G, Hoeber H (2003) A Fram Strait cyclone: properties and impact on ice drift as measured by aircraft and buoys. J Geophys Res Atmos. https://doi.org/10.1029/2002jd002638

Brümmer B, Schröder D, Müller G, Spreen G, Jahnke-Bornemann A, Launiainen J (2008) Impact of a Fram Strait cyclone on ice edge, drift, divergence, and concentration: possibilities and limits of an observational analysis. J Geophys Res Oceans. https://doi. org/10.1029/2007jc004149

Cavalieri D, Parkinson C (2012) Arctic sea ice variability and trends, 1979-2010. Cryosphere 6:881-889. https://doi.org/10.5194/ tc-6-881-2012

Cohen J, Screen JA, Furtado JC et al (2014) Recent Arctic amplification and extreme mid-latitude weather. Nat Geosci 7:627-637. https://doi.org/10.1038/ngeo2234

Dierer S, Schlünzen K, Birnbaum G et al (2005) Atmosphere-Sea Ice interactions during a cyclone passage investigated by using model simulations and measurements. Mon Weather Rev 133:36783692. https://doi.org/10.1175/mwr3076.1

Finnis J, Holland M, Serreze M, Cassano J (2007) Response of Northern Hemisphere extratropical cyclone activity and associated precipitation to climate change, as represented by the Community Climate System Model. J Geophys Res Biogeosci. https://doi. org/10.1029/2006jg000286 
Hilmer M, Harder M, Lemke P (1998) Sea ice transport: a highly variable link between Arctic and North Atlantic. Geophys Res Lett 25:3359-3362. https://doi.org/10.1029/98g152360

Hodges K, Lee R, Bengtsson L (2011) A comparison of extratropical cyclones in recent reanalyses ERA-Interim, NASA MERRA, NCEP CFSR, and JRA-25. J Clim 24:4888-4906. https://doi. org/10.1175/2011jcli4097.1

Inoue J, Hori M (2011) Arctic cyclogenesis at the marginal ice zone: a contributory mechanism for the temperature amplification? Geophys Res Lett. https://doi.org/10.1029/2011g1047696

Inoue J, Hori M, Takaya K (2012) The role of Barents sea ice in the wintertime cyclone track and emergence of a warm-Arctic cold-Siberian anomaly. J Clim 25:2561-2568. https://doi. org/10.1175/JCLI-D-11-00449.1

Koenigk T, Mikolajewicz U, Haak H, Jungclaus J (2006) Variability of Fram Strait sea ice export: causes, impacts and feedbacks in a coupled climate model. Clim Dyn 26(1):17-34. https://doi. org/10.1007/s00382-005-0060-1

Kwok R (2007) Near zero replenishment of the Arctic multiyear sea ice cover at the end of 2005 summer. Geophys Res Lett. https:// doi.org/10.1029/2006g1028737

Kwok R, Cunningham G, Wensnahan M et al. (2009) Thinning and volume loss of the Arctic Ocean sea ice cover: 2003-2008. J Geophys Res Oceans. https://doi.org/10.1029/2009jc005312

Lambert S, Fyfe J (2006) Changes in winter cyclone frequencies and strengths simulated in enhanced greenhouse warming experiments: results from the models participating in the IPCC diagnostic exercise. Clim Dyn 26:713-728. https://doi.org/10.1007/ s00382-006-0110-3

Lammert A, Brümmer B, Kaleschke L (2009) Observation of cyclone-induced inertial sea-ice oscillation in Fram Strait. Geophys Res Lett. https://doi.org/10.1029/2009g1037197

Laxon S, Giles K, Ridout A et al (2013) CryoSat-2 estimates of Arctic sea ice thickness and volume. Geophys Res Lett 40(4):732737. https://doi.org/10.1002/grl.50193

Leppäranta M (2005) The drift of sea ice. Springer, Heidelberg, p 266

Lindsay R, Schweiger A (2015) Arctic sea ice thickness loss determined using subsurface, aircraft, and satellite observations. Cryosphere 9(1):269-283. https://doi.org/10.5194/tc-9-269-2015

Lindsay R, Zhang J (2005) The thinning of Arctic sea ice, 19882003: Have we passed a tipping point? J Clim 18(22):48794894. https://doi.org/10.1175/jcli3587.1

Lindsay R, Zhang J, Schweiger A et al (2009) Arctic sea ice retreat in 2007 follows thinning trend. J Clim 22(1):165-176. https:// doi.org/10.1175/2008jcli2521.1

Liptak J, Strong C (2013) Propagating atmospheric patterns associated with sea ice motion through the Fram Strait. J Clim 26(9):2992-2997. https://doi.org/10.1175/jcli-d-12-00599.1

Losch M, Menemenlis D, Campin J et al (2010) On the formulation of sea-ice models. Part 1: effects of different solver implementations and parameterizations. Ocean Model 33:129-144. https:// doi.org/10.1016/j.ocemod.2009.12.008

Marshall J, Adcroft A, Hill C et al (1997a) A finite-volume, incompressible Navier Stokes model for studies of the ocean on parallel computers. J Geophys Res Oceans 102(C3):5753-5766. https ://doi.org/10.1029/96jc02775

Marshall J, Hill C, Perelman L, Adcroft A (1997b) Hydrostatic, quasi-hydrostatic, and nonhydrostatic ocean modeling. J Geophys Res Oceans 102(C3):5733-5752. https://doi. org/10.1029/96jc02776

McCabe G, Clark M, Serreze M (2001) Trends in Northern Hemisphere surface cyclone frequency and intensity. J Clim 14(12):2763-2768. https://doi.org/10.1175/1520-0442(2001)014<2763:tinhsc>2.0.co;2

Menemenlis D, Fukumori I, Lee T (2005a) Using Green's functions to calibrate an ocean general circulation model. Mon Weather Rev 133(5):1224-1240. https://doi.org/10.1175/mwr2912.1
Menemenlis D, Hill C, Adcrocft A et al (2005b) NASA supercomputer improves prospects for ocean climate research. EOS Trans AGU 86(9):89-96. https://doi.org/10.1029/2005eo090002

Menemenlis D, Campin J, Heimbach P et al (2008) ECCO2: high resolution global ocean and sea ice data synthesis. Mercat Ocean Q Newsl 31:13-21.

Murray R, Simmonds I (1995) Responses of climate and cyclones to reductions in Arctic winter sea ice. J Geophys Res Oceans 100(C3):4791-4806. https://doi.org/10.1029/94jc02206

Nguyen A, Menemenlis D, Kwok R (2009) Improved modeling of the Arctic halocline with a subgrid-scale brine rejection parameterization. J Geophys Res Oceans 114:C11014. https://doi. org/10.1029/2008JC005121

Nguyen A, Menemenlis D, Kwok R (2011) Arctic ice-ocean simulation with optimized model parameters: approach and assessment. J Geophys Res Oceans. https://doi.org/10.1029/2010JC006573

Onogi K, Tsutsui J, Koide H et al (2007) The JRA-25 reanalysis. J Meteorol Soc Jpn 85(3):369-432. https://doi.org/10.2151/ jmsj.85.369

Overland J, Wang M (2010) Large-scale atmospheric circulation changes are associated with the recent loss of Arctic sea ice. Tellus A 62(1):1-9. https://doi.org/10.3402/tellusa.v62il.15661

Polyakov I, Walsh J, Kwok R (2012) Recent changes of Arctic multiyear sea ice coverage and the likely causes. Bull Am Meteorol Soc 93(2):145-151. https://doi.org/10.1175/bams-d-11-00070.1

Rogers J, Yang L, Li L (2005) The role of Fram Strait winter cyclones on sea ice flux and on Spitsbergen air temperatures. Geophys Res Lett. https://doi.org/10.1029/2004g1022262

Screen J, Simmonds I (2010) The central role of diminishing sea ice in recent Arctic temperature amplification. Nature 464(7293):1334 1337. https://doi.org/10.1038/nature09051

Serreze M (1995) Climatological aspects of cyclone development and decay in the Arctic. Atmos Ocean 33(1):1-23. https://doi. org/10.1080/07055900.1995.9649522

Serreze M, Barry R (1988) Synoptic activity in the Arctic Basin, 1979-85. J Clim 1(12):1276-1295. (https://doi. org/10.1175/1520-0442(1988)001<1276:saitab>2.0.co;2)

Serreze M, Carse F, Barry R, Rogers J (1997) Icelandic low cyclone activity: climatological features, linkages with the $\mathrm{NAO}$, and relationships with recent changes in the Northern Hemisphere Circulation. J Clim 10(3):453-464. (https://doi. org/10.1175/1520-0442(1997)010<0453:ilcacf > 2.0.co;2)

Serreze M, Barrett A, Slater A et al. (2006) The large-scale freshwater cycle of the Arctic. J Geophys Res Oceans. https://doi. org/10.1029/2005jc003424

Simmonds I, Burke C, Keay K (2008) Arctic climate change as manifest in cyclone behavior. J Clim 21(22):5777-5796. https://doi. org/10.1175/2008jcli2366.1

Spall M (2007) Circulation and water mass transformation in a model of the Chukchi Sea. J Geophys Res Oceans. https://doi. org/10.1029/2005jc003364

Spreen G, Kern S, Stammer D, Hansen E (2009) Fram Strait sea ice volume export estimated between 2003 and 2008 from satellite data. Geophys Res Lett. https://doi.org/10.1029/2009g1039591

Stroeve J, Serreze M, Barrett A, Kindig D (2011) Attribution of recent changes in autumn cyclone associated precipitation in the Arctic. Tellus A 63(4). https://doi.org/10.3402/tellusa.v63i4.15846

Thorndike AS, Colony R (1982) Sea ice motion in response to geostrophic winds. J Geophys Res 87(C8):5845-5852. https://doi. org/10.1029/JC087iC08p05845

Tsukernik MA (2007) Characteristics of the winter cyclone activity in the northern North Atlantic and its impact on the Arctic freshwater budget. Doctoral dissertation, University of Colorado at Boulder

Ulbrich U, Leckebusch G, Pinto J (2009) Extra-tropical cyclones in the present and future climate: a review. Theor Appl Climatol 96(1-2):117-131. https://doi.org/10.1007/s00704-008-0083-8 
Wang X, Swail V, Zwiers F (2006) Climatology and changes of extratropical cyclone activity: comparison of ERA-40 with NCEPNCAR reanalysis for 1958-2001. J Clim 19(13):3145-3166. https ://doi.org/10.1175/jcli3781.1

Wei L, Qin T, Li C (2017) Seasonal and inter-annual variations of Arctic cyclones and their linkage with Arctic sea ice and atmospheric teleconnections. Acta Oceanol Sin 36(10):1-7. https://doi. org/10.1038/ngeo 1438

Yin J (2005) A consistent poleward shift of the storm tracks in simulations of 21 st century climate. Geophys Res Lett. https://doi. org/10.1029/2005g1023684

Zhang X, Walsh J, Zhang J et al. (2004) Climatology and interannual variability of Arctic cyclone activity: 1948-2002.
J Clim 17(12):2300-2317. https://doi.org/10.1175/15200442(2004)017<2300:caivoa>2.0.co;2

Zhang X, Sorteberg A, Zhang J et al. (2008) Recent radical shifts of atmospheric circulations and rapid changes in Arctic climate system. Geophys Res Lett. https://doi.org/10.1029/2008g1035607

Zhang X, Lu C, Guan Z (2012) Weakened cyclones, intensified anticyclones and recent extreme cold winter weather events in Eurasia. Environ Res Lett 7(4):044044. https://doi.org/10.1088/17489326/7/4/044044

Zhang J, Lindsay R, Schweiger A, Steele M (2013) The impact of an intense summer cyclone on 2012 Arctic sea ice retreat. Geophys Res Lett 40(4):720-726. https://doi.org/10.1002/grl.50190 